\title{
Limits of the evocative pancreatic function test in the diagnosis of low-grade pancreatitis
}

\author{
R. VAN DER HOEDEN, P. WETTENDORFF, AND A. DELCOURT \\ From the Departments of Gastroenterology and Internal Medicine, Ixelles Hospital, Belgium
}

SUMMARY At a certain level of stimulation of the enzymatic secretions of the pancreas utilizing duodenal hormones and caerulein in normal subjects, the hourly urinary amylase output increases beyond normal values. Under these conditions, the so-called evocative pancreatic function test becomes unusable for the diagnosis of chronic pancreatitis in the early stages.

The clinical exploration of the pancreas by the duodenal hormones-secretin and pancreozymindoes not consist only in the measurement of the functional capacity of the gland in the juice collected by duodenal intubation but it is possible to combine this with measuring the enzyme activity in the blood by the evocative pancreatic function test.

Burton, Hammond, Harper, Howat, Scott, and Varley (1960) have shown that while in normal subjects the administration of submaximal doses of these duodenal hormones does not modify the blood amylase and lipase levels, in cases of pancreatitis these levels increase as long as the lesions of the gland are not too severe. In previous studies (Delcourt and Wettendorff, 1964; Wettendorff, Hensgens van der Hoeden, and Delcourt, 1970) it has been demonstrated that from this point of view the hourly measurement of the urinary amylase output is more sensitive than that of the blood amylase level. In six cases of pancreatitis, the urinary amylase output was markedly increased while the composition of the pancreatic juice collected during a duodenal intubation after hormonal stimulation was normal in four cases and only moderately deficient in two. The stimulation of the pancreas was produced by half-hourly intravenous injections of secretin followed by $1.5 \mathrm{U} / \mathrm{kg}$ pancreozymin (Boots). Recently we modified our protocol for pancreatic investigation, by the use of a more powerful preparation of secretin (GIH) and by a double stimulation of pancreatic enzyme secretion with caerulein (Farmitalia) and CCK (GIH). Under these conditions we observed in certain normal subjects an increase in urinary amylase output greatly exceeding the values previously considered as the upper limits of normal.

Received for publication 3 July 1973.

\section{Material and Methods}

Duodenal intubation was carried out using a technique previously described by van der Hoeden $e t$ al (1971). Secretin (GIH) was injected by the intravenous route at a dose of $1 \mathrm{U} / \mathrm{kg}$ at the same time as caerulein (Farmitalia) at a dose of $40 \mathrm{ng} / \mathrm{kg}$. As we have shown in a recent study (Fox, van der Hoeden, and Delcourt, 1971), the latter substance has the same physiological action on the enzymatic secretion of the pancreas and on the biliary tract as that of pancreozymin with the advantage that it is pure. At a dose of $40 \mathrm{ng} / \mathrm{kg}$, the activity is comparable to that of pancreozymin (Boots) at a dose of $1.5 \mathrm{U} / \mathrm{kg}$. After injection, the biliary-pancreatic secretions were continuously aspirated for 30 minutes and divided into three 10-minute samples. With this double stimulation of the pancreas affecting at the same time excretion of bicarbonate and enzymes, we thought we could, in half an hour, carry out a simple exploration of the pancreas as well as of the biliary tract. When the gallbladder was emptied, we injected at the thirtieth minute of the test $1 \mathrm{U} / \mathrm{kg}$ CCK (GIH) to provoke further enzymatic secretion from the pancreas without being affected by biliary secretions. Pancreatic secretions were then continually aspirated for a further $\mathbf{3 0}$ minutes and once more divided into three samples of 10 minutes each.

The estimation of bicarbonate was carried out using the gasometric method of Van Slijke adapted for Technicon and that of amylase using the idiometric method of Van Loon also adapted for Technicon and the results expressed in Van Loon units (VLU).

The hourly urinary amylase level was studied during the eight hours which followed, using a technique previously established by Wettendorff et al (1970). 
The test was carried out on 12 subjects free from alcoholism, diabetes, or disease of the pancreas and with normal renal function. There were 10 men and two women, aged between 19 and 71 .

\section{Results}

\section{SECRETORY RESPONSE OF THE PANCREAS}

The average and extreme values for the four parameters studied on the six 10-minute samples were: volume, $290 \mathrm{ml}$ (177-413); maximum concentration of bicarbonate, 93 m-equiv/l (68-120); bicarbonate output, 21.3 m-equiv (13.4-31.6); and amylase output, 245000 VLU (142000-415000). Except for the maximum concentration of bicarbonate, which did not change, these values are markedly greater than those we had obtained using Boots secretin $(1.5 \mathrm{U} / \mathrm{kg})$ and pancreozymin $(1.5 \mathrm{U} / \mathrm{kg})$ or caerulein (Farmitalia) (40 ng/kg) (Fox et al, 1971; van der Hoeden et al, 1971).

Table I shows the results obtained with the two types of stimulation.

HOURLY URINARY AMYLASE OUTPUT

Although, after stimulation using pancreozymin (Boots) or caerulein at the doses mentioned above, we observed no modification in the hourly urinary amylase output in normal subjects we noted a marked increase after stimulation using caerulein-cecekin (GIH). The average of the maximum output increased from $139 \pm 19$ (SEM) before stimulation to $354 \pm 47$ (SEM) after stimulation. Moreover, in a previous

\begin{tabular}{|c|c|c|c|c|c|}
\hline $\begin{array}{l}\text { Number } \\
\text { of Cases }\end{array}$ & Method & Volume $(m l)$ & $\begin{array}{l}\text { Maximum Bicarbonate } \\
\text { Concentration } \\
\text { (m-equiv/l) }\end{array}$ & $\begin{array}{l}\text { Bicarbonate Output } \\
\text { (m-equiv/l) }\end{array}$ & $\begin{array}{l}\text { Amylase Output } \\
\left(U X 10^{3}\right)\end{array}$ \\
\hline 12 & $\begin{array}{l}\text { Secretin (GIH) (1 U/kg) } \\
\text { Caerulein (40 mg/kg) } \\
\text { Cecekin (GIH) (1 U/kg) }\end{array}$ & $\begin{array}{l}290 \\
(177-413)\end{array}$ & $\begin{array}{l}93 \\
(68-120)\end{array}$ & $\begin{array}{l}21 \cdot 3 \\
(13 \cdot 4-31 \cdot 6)\end{array}$ & $\begin{array}{l}245 \\
(142-415)\end{array}$ \\
\hline
\end{tabular}

Table I Results of the two types of tests in normal patients expressed as means and ranges

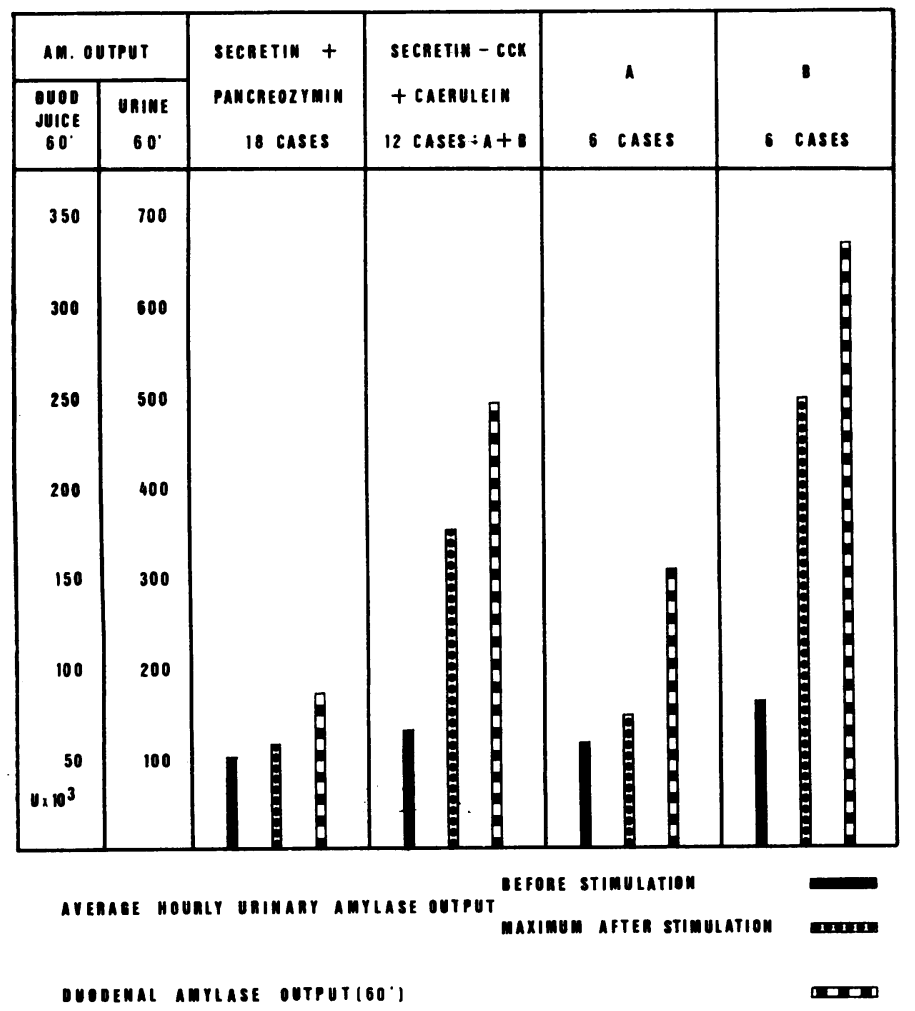

Fig 1 Values for urinary and duodenal amylase output in two groups of normal subjects after hormonal stimulation. 
study, we had considered 300 Units as the upper limit of normal. If we now consider the maximum outputs in each of the 12 cases studied, we notice that the value of $300 \mathrm{U} / \mathrm{hr}$ is only exceeded in six of these (fig 1). If we examine the pancreatic amylase output in the duodenal juice, we notice that the same six patients also secreted a great deal more enzyme than the six others.

Figure 2 shows the profile of urinary amylase output during the test. Two groups of subjects are separated. The first group (A), in which the amylase output in urine does not increase above normal, and in duodenal juice is distinctly less important than in the other group (B), in which abnormal values for urinary amylase output are demonstrated after stimulation of the pancreas. The level of amylase output in duodenal juice above which an increase of amylase output in urine may appear lies at about $180000 \mathrm{VLU} /$ hour. We had previously observed this abnormality during continuous perfusions of secretin, when a strong stimulation of pancreatic enzymes was produced by giving increasing isolated doses of caerulein with the purpose of studying the action of this polypeptide on the normal pancreas. Table II gives the results for five experiments of this type. In three cases, the urinary amylase output per hour exceeded 300 units with a very high duodenal aspiration output, namely, 337000-462000-596000 VLU in 60 minutes. It should, however, be noted that in one case while the amylase output in duodenal juice was very high (430000 VLU) the

\begin{tabular}{lllll}
\hline & \multicolumn{2}{c}{ Total Amylase Output $\left(U 10^{3}\right)$} & \multicolumn{2}{c}{ Urinary Amylase per Hour } \\
\cline { 5 - 5 } & & Before & After \\
\hline 1 & 125 & - & 121 \\
2 & 430 & 65 & 102 \\
3 & 570 & 235 & 596 \\
4 & 670 & 150 & 337 \\
5 & 840 & 80 & 462 \\
\hline
\end{tabular}

Table II Amylase outputs after continuous perfusion of secretin + caerulein

urinary amylase output remained normal, for reasons which we do not understand.

\section{Discussion}

The evocative pancreatic function test based on a modification of the hourly urinary amylase output as described previously (Wettendorff et al, 1970) implied that there was no increase in this value in normal subjects. We observe that by increasing the hormonal stimulation the urinary amylase output exceeds the admitted upper normal limit (300 VLU/ hour) when the enzyme output obtained by duodenal aspiration lies above a level of about $180 / 000 \mathrm{U} /$ hour. This observation suggests that the evocative pancreatic function test loses its significance when it is carried on in conditions which render it positive in normal subjects. It can no longer differentiate patients suffering from a low-grade pancreatitis from normal subjects. This is in agreement with the con-



BUODENAL JHICE

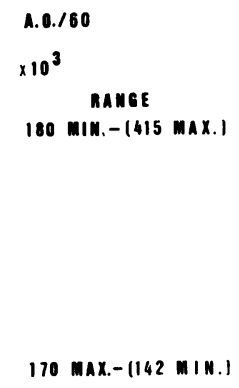

Fig 2 Hourly amylase output in urine after hormonal stimulation of the pancreas. 
clusions of Hartley, Gambill, Engstrom, and Summerskill (1966); these authors administered $2 \mathrm{U} / \mathrm{kg}$ secretin and $3 \mathrm{U} / \mathrm{kg}$ pancreozymin with a test meal. In normal subjects the hourly urinary amylase output never exceeds our admitted upper limit of $300 \mathrm{VLU} / \mathrm{hour}$, even during the postprandial period.

Caerulein (FI 6934) was placed at our disposal by Farmitalia (Milan).

We wish to thank $\mathrm{Dr} \mathrm{Cl}$. Jeanty who helped us to carry out these tests, Mrs Girard and Mrs Steckelmacher who helped to carry out the practical side of these tests, Mrs Declercq and Miss Bouchei who carried out the chemical analysis in the laboratory of Dr Fr van der Veiken, whose assistance is greatly appreciated.
This work was supported by FRSM research funds.

\section{References}

Burton, P., Hammond, E. M., Harper, A. A., Howat, H. T., Scott, J. E., and Varley, H. (1960). Serum amylase and serum lipase levels in man after administration of secretin and pancreozymin. Gut, 1, 125-139.

Delcourt, A., and Wettendorff, P. (1964). La clearance rénale de l'amylase à l'état normal et au cours d'affections pancréatiques. Acta clin. Belg., 19, 265-270.

Fox, A., van der Hoeden, R., and Delcourt, A. (1971). Exploration du pancréas exocrine par le test sécrétine-céruléine. Acta gastro.-ent. belg., 34, 721-729.

Hartley, R. C., Gambill, E. A., Engstrom, G. W., and Summerskill, W. H. J. (1966). Pancreatic exocrine function. Amer. J. dig. Dis., 11, 27-39.

van der Hoeden, R., Delcourt, A., and Algoet, P. (1971). Le test sécrétine pancréozymine: recherche d'un paramètre significatif. Acta Gastro.-ent. belg., 34, 34-45.

Wettendorff, P., Hensgens, C., van der Hoeden, R., and Delcourt, A. (1970). Le débit amylasurique horaire après stimulation par les hormones duodénales. Arch. Mal. Appar. dig., 59, 71-76.

\section{The September 1973 Issue}

\section{THE SEPTEMBER 1973 ISSUE CONTAINS THE FOLLOWING PAPERS}

Small intestinal permeability in animals and man C. A. LOEHRY, J. KINGHAM, AND JUNE BAKER

The electrical and motor actions of gastrointestinal hormones on the duodenum in man W. E. WATERFALL, H. L. DUTHIE, AND B. H. BROWN

Observations upon ammonia absorption from the human ileum J. D. SWALES, M. PAPADIMITRIOU, AND O. M. WRONG

Cell kinetics in flat (avillous) mucosa of the human small intestine NICHOLAS WRIGHT, ALEXANDER WATSON, ADRIAN MORLEY, DAVID APPLETON, AND JANET MARKS

Double-blind trial of deglycyrrhizinated liquorice in gastric ulcer ALICE ENGQVIST, FREDRIK VON FEILITZEN, EINAR PYK, AND HANS REICHARD

Fatty acid composition of plasma lipoproteins in control subjects and in patients with malabsorption T. SHIMOYAMA, H. KIKUCHI, M. PRESS, AND G. R. THOMPSON
Serum immunoglobulins in calcific pancreatitis SIMMY BANK, B. H. NOVIS, E. PETERSEN, E. DOWDLE, AND I. N. MARKS

Simulation of macroamylasaemia by salivary-type ('S type') hyperamylasaemia J. E. BERK, L. FRIDHANDLER, AND K. MONTGOMERY

Trichobezoar, gastric polyposis, protein-losing gastroenteropathy, and steatorrhea A. HOSSENBOCUS AND D. G. COLIN-JONES

Inhibition of leucocyte migration by tumourassociated antigens of the colon and rectum P. J. GUILLOU AND G. R. GILES

Disturbance of cell-mediated immunity in patients with carcinoma of colon and rectum O. N. MANousos, J. ECONOMIDOU, CH. PATHOULI, AND G. MERIKAS

Progress report Is secretion secreted ? K. G. WORMSLEY

Notes and activities

Copies are still available and may be obtained from the PUBLISHING MANAGER, BRITISH MEDICAL ASSOCIATION, TAVISTOCK SQUARE, LONDON, WC1H 9JR, price $87 \frac{1}{2} \mathrm{p}$. 